Seyahat ve Otel İşletmeciliği Dergisi/

Journal of Travel and Hospitality Management

16 (3), 2019, 437-455.

Gönderim Tarihi:12.07.2019

Kabul Tarihi:16.09.2019

\title{
Turizm Sektöründe Müşterilerin Bilgi Üretici Rolü: Adıyaman'daki Turistik Çekiciliklere Yönelik Tripadvisor Sitesinde Yer Alan Yorumlar Üzerine Bir Araştırma
}

\section{The Role of Information Producer of Customer in the Tourism Sector: A Research at the Comments on the Tripadvisor Website for Touristic Attractions in Adıyaman}

\author{
Dr. Öğr. Üyesi Reşat ARICA \\ Adıyaman Üniversitesi \\ Turizm Fakültesi \\ E-posta: rarica@adiyaman.edu.tr
}

\author{
Dr. Öğr. Üyesi Abdülkadir ÇORBACI \\ Adıyaman Üniversitesi \\ Turizm Fakültesi \\ E-posta: kcorbaci@adiyaman.edu.tr
}

\section{Öz}

Araştırmanın amacı, turistlerin sosyal iletişim ağlarında yaptıkları paylaşımlarla turistik bölge imajına yönelik ürettiği bilgilerin incelenmesidir. Bununla birlikte turistlerin paylaşımlarıyla benzer ilgi alanına sahip potansiyel müşteriler, turistik bölge ve işletme yöneticileri için üstlendiği bilgi üretici rolün değerlendirilmesi amaçlanmaktadır. Bu amaç odağında, Adıyaman'daki turistik çekiciliklere yönelik TripAdvisor sitesinde yapılan yorumlar içerik ve tanımlayıcı analiz yöntemiyle incelenmiştir. Araştırma sonuçlarına göre, turistlerin Adıyaman'daki turistik çekiciliklere yönelik yorumları 11 kategoriye ayrımıştır. Bu kategoriler: (i) doğal ve turistik kaynaklar, (ii) genel yatırımlar, (iii) turistik yatırımlar, (iv) turistik eğlence ve aktivite olanakları, (v) turistik eserlerin kültürel, tarihi ve mimari değeri (vi) ekonomik ve politik faktörler, (vii) doğal çevre, (viii) sosyal çevre, (ix) turistik bölgenin atmosferi, (x) yetkililer ve çalışanlar ve (xi) öneriler olarak isimlendirilmiştir. Turistlerin en fazla yorum yaptığı kategori (v) turistik eserlerin kültürel, tarihi ve mimari değeri iken, en az yorumlanan kategori (ii) genel yatırımlardır. Çalışmada elde edilen sonuçlar, turistlerin bölgeye yönelik imaj algılarının turizm sektöründeki yöneticiler tarafından anlaşılmasına yardımcı olmakla kalmayacak, aynı zamanda turistlerin bilgi üretici rolünün turizm sektörü bağlamında incelenmesi konusunda araştırmacılara izlek oluşturacaktır.

Anahtar Kelimeler: Teknoloji, Sosyal İletişim Ağları, TripAdvisor, Turizm, Ortak Üretim.

\section{Abstract}

The aim of the research is to examine the information produced by the tourists about the image of the touristic region through the shares they make on social communication networks. However, it is aimed to evaluate the information co-producing role undertaken by potential customers, touristic regions and business managers with similar interests with the sharing of tourists. For this purpose, comments on the TripAdvisor website for tourist attraction in Adıyaman were examined by content and descriptive analysis methods. According to the results of the research, tourists' comments about tourist attractions in Adıyaman are divided into eleven categories. These categories are named as: (i) natural and touristic resources, (ii) general investments, (iii) touristic investments, (iv) entertainment and activities for tourism, (v) cultural, historical and architectural value of tourist attractions (vi) economic and political factors, (vii) natural environment, (viii) social environment, (ix) atmosphere of the destination, (x) authorities and employees, (xi) suggestions. Among these categories, most commented category is the cultural, historical and architectural value of the touristic works, while the least commented category is general investments. The results of this study will not only help the tourism sector to understand the image perceptions of the tourists by the managers of the region, but will also provide the researchers with an insight into the investigation of the information co-producing role of the tourists in the tourism sector.

Key Words: Technology, Social Networks, TripAdvisor, Tourism, Co-creation. 


\section{Giriş}

Sosyal medyanın insanların geniş kapsamlı ağlar ve sanal topluluklar aracılığıyla iletişim ve etkileşim kurmalarına izin vermesi dünyayı değiştirmiştir (Buhalis ve Foerste, 2015). Web 2.0 teknolojilerindeki gelişimin ürünü olan sosyal medya, yeni bir iletişim aracı olarak bireylerin sorunlarını ve ilgi alanlarını paylaştığı bir kullanım alanı haline gelmiştir (Qualman, 2012). Turizm bağlamında değerlendirildiğinde, sosyal medyanın gelişimi ve kullanımının sektöre etkisi iki şekilde gerçekleşmiştir. Bunlardan ilki, turistik bölge ve işletme yöneticilerinin sosyal medyayı potansiyel müşterilere ulaşmak, onları ikna etmek, bölgeye çekmek, deneyimleri yönlendirmek ve şekillendirmek amaçlı kullanımının yol açtığı etkidir (Jacobsen ve Munar, 2012; Molinillo, Liebana-Cabanillas, Anaya-Sanchez ve Buhalis, 2018; Zhao, Xu ve Wang, 2019). İkincisi ise sosyal medyanın turistler tarafından deneyim öncesi araştırmalar yapmak, seyahat düzenlemek ve deneyim sonrası bilgi paylaşma işlemlerini yaptığı bir etkileşim alanı olarak kullanılmasının neden olduğu etkidir (Jacobsen ve Munar, 2012; Rihova, Buhalis, Moital ve Gouthro, 2015). Sosyal medyanın sektörel ölçekte kullanımının yaygınlaşması ve turistler arasında kullanımının yaygınlaşması bilgi arama ve paylaşımı amacıyla kullanılan sosyal iletişim ağlarının gelişimini beraberinde getirmektedir (Yoo ve Gretzel, 2009; Bulut ve Karabulut, 2018). Facebook, Twitter, Instagram gibi sanal toplulukların bir araya geldiği iletişim ağları ve Trip Advisor, Trivago gibi gezi deneyim ve hikâyelerine ilişkin tatmin ve tatminsizlik yorumlarının paylaşıldığı çevrimiçi sitelerin sayısı ve kullanımı gün geçtikçe yaygınlaşmaktadır (Munar ve Jacobsen 2014). Sosyal iletişim ağlarında turistler tarafından bölgenin çekicilikleri, konaklama olanakları, yeme-içme mekânları gibi arz öğelerine ilişkin paylaşılan fotoğraflar, yorumlar, şikâyetler, öneriler yalnızca müşterilerini ve rakiplerini anlamaya çalışan işletme yöneticileri için değil, aynı zamanda potansiyel müşterilerin seyahat kararı alma sürecinde de önemli işlev görmektedir (Kim, Kim ve Heo, 2015; Narangajavana, Fiol, Tena, Artola ve Garcia, 2017).

Sosyal iletişim ağlarında görülen gelişmelerle işletmelerin tek tarafı bilgi üretici olduğu anlayıştan, turistlerin bilgi üretimi, bilgi yönetimi ve deneyim üretiminde ortak üretici rol üstlendiği anlayışa geçiş (Arıca ve Çorbacı, 2019) ve bu geçişin sektörel düzeydeki etkileri, araştırmacıları turistlerin sosyal medya paylaşımlarına dair araştırmalar yapmaya sevk etmektedir (Kim ve diğ. 2015). Araştırmacılar turizm sektörünün çeşitli alanlarından hizmet alan ve aldığı hizmetlere ilişkin paylaşımlarıyla bilgi üreten turistlerin deneyimlerinin ana boyutlarını belirlemek amacıyla sosyal iletişim ağlarındaki deneyim paylaşımlarını analiz etmektedir (Buhalis ve Foerste, 2015). Bir kısım araştırmacı, turistlerin sosyal medyada ürettiği bilgiler ekseninde turistik bölgelerdeki konaklama işletmeleri (O’Connor, 2010; Kim ve diğ. 2015; Berezina, Bilgihan, Çobanoğlu ve Okumus, 2016; Zhao ve diğ. 2019), yiyecek ve içecek işletmeleri (Zhang, Ye, Law ve Li, 2010; Gao, Tang, Wang ve Yin, 2018), havayolu işletmeleri (Brochado, Rita, Oliveira ve Oliveira, 2019) gibi turistik işletmelere yönelik paylaşımları analiz etmiştir. Araştırmacıların bir kısmı ise turistlerin sosyal medyada ürettiği bilgiler vasıtasıyla turistik bölgelerin imajı ve bölge imajını etkileyen doğal, kültürel ve tarihsel çekiciliklerini değerlendirmiştir (Dwivedi, 2009; Sun, Ryan ve Pan, 2015; Yeşilyurt ve Arıca, 2018; Hao, Xu ve Zhang, 2019). Sosyal iletişim ağlarında yapılan paylaşımlar üzerine gerçekleştirilen çalışmalara karşın, müşterilerin sosyal iletişim ağlarında yaptığı paylaşımlarla üstlendiği bilgi üretici rolüne dair tespitler yetersiz kalmıştır.

Bu çıkış noktasından hareketle hazırlanan araştırmanın amacı; turistlerin sosyal iletişim ağlarında yaptıkları paylaşımlarla turistik bölge imajına yönelik ürettiği bilgilerin incelenmesidir. Bununla birlikte turistlerin paylaşımlarılla benzer ilgi alanına sahip 
potansiyel müşteriler, turistik bölge ve işletme yöneticileri için üstlendiği bilgi üretici rolün incelenmesi amaçlanmaktadır. Araştırmada turistler tarafından üretilen bilgiyi somut göstergelerle ortaya koymak amacıyla Adıyaman'daki turistik çekiciliklere yönelik TripAdvisor sitesinde yapılan paylaşım ve yorumlar değerlendirilmiş, turistler tarafından üretilen bilgiler sınıflandırımıştır. Araştırma sosyal iletişim ağlarında yapılan yorumlar üzerine çalışma yapacak araştırmacıların, turistlerin bilgi üretici rolünden hareketle paylaşım ve yorumları değerlendirmesi noktasında yönlendirici olması açısından önem atfetmektedir. Ayrıca araştırmada müşteri eksenli yapılanan günümüz pazarında turizm işletmelerine ve yöneticilerine sosyal iletişim ağlarının işlevine dair öneriler sunulmaktadır.

\section{Alanyazın}

Turistik bölge, sahip olduğu çeşitli turizm kaynaklarıyla turistleri çeken ve yoğun olarak ziyaretlere ev sahipliği yapan, birçok kurum ve kuruluşun sağladığı doğrudan ve dolaylı turizm hizmetlerinin bütününden oluşan karmaşık bir üründür. Bu özellikleri itibariyle turistik bölgeler, turizmin en önemli öğelerinden biri olmakla birlikte yönetilmesi ve pazarlanması en zor turistik ürünler olarak nitelendirilmektedir (Özdemir, 2008). Turistik bölgelerin pazarlama unsurlarından biri bölgenin imajdır (Baloglu ve McCleary, 1999). Avcıkurt (2010: 35) imajı, hedef kitleyi oluşturan bireylerin çoğunluğunun bir ülke, konu veya ürünle ilgili düşünceleri ve değer yargıları olarak açıklamaktadır. Turistik bölge imajı ise bir kişinin bir varış noktası hakkında sahip olduğu inanç, fikir ve izlenimlerin toplamı olarak tanımlanmaktadır (Crompton, 1979: 18). Bir başka tanıma göre turistik bölge imajı, bir kişi ya da grubun belirli bir mekân hakkında sahip olduğu tüm bilgi, izlenim, önyargı ve duygusal düşüncelerdir (Baloglu ve McCleary, 1999: 871). Turistlerin satın alma kararı ve memnuniyet düzeyini etkileyen en önemli unsurlardan biri olan imaj (Baloglu ve McCleary, 1999; Özdemir, 2008), turistik bölgenin başarısını etkileyen temel faktör ve sektörel rekabetin belirleyici unsurudur (Beerli ve Martin, 2004; Chen ve Tsai, 2007). Bu bağlamda turistik bölgelerde pazarlama girişimleri temelde olumsuz imajın yerine olumlu imaj yaratmak ve bu imajı kuvvetlendirmek üzerine kurgulanmaktadır (Özdemir, 2008). Buna karşın, turistik bölge imajı bağımsız birçok etkenden etkilenme ve farklı unsurların katkılarıyla oluşmaktadır (Beerli ve Martin, 2004). Bu etkenlerin başlıcaları; turistlerin edindikleri bilgi kaynakları, sosyopsikolojik seyahat davranışları ve turistlerin demografik özellikleriyle geçmiş seyahat tecrübeleridir (Özdemir, 2008). Ancak günümüzde bilgi kaynakları imajı yöneten temel değişken olarak, turistlerin tatil kararı vermesinde ve tatil yeri seçimi kararı almasında doğrudan etkili olduğundan büyük öneme sahiptir. Alanyazında turistik bölge imajı oluşturan ve etkileyen başlıca bilgi kaynakları şöyle açıklanmaktadır: Gazete, dergi, televizyon ve internet gibi medya araçlarıyla birlikte, seyahat acentaları ve tur operatörleri gibi uzman birimler başat bilgi kaynaklarıdır (Beerli ve Martin 2004). Bununla birlikte bir kısım araştırmada turistler bölge imajının oluşturulmasında önemli bir bilgi kaynağı olarak kabul edilmektedir. (Akyurt ve Atay, 2009; Dwivedi, 2009). Turistler geçmiş tecrübeleri, ağızdan ağıza iletişim yoluyla sunduğu bilgiler (Baloglu ve McCleary, 1999) ve sosyal iletişim ağları vasıtasıyla ürettiği bilgiler ve yaptıkları paylaşımlarla imaj oluşturulmasında en etkili bilgi kaynakları arasında gösterilmektedir (Jacobsen ve Munar, 2012; Rihova ve diğ. 2015). Turistlerin ağızdan ağız iletişim yoluyla ve sosyal iletişim ağlarında üstlendiği bilgi üretici işleviyle turistik bölgeye dair ürettiği bilgilerin bölge imajına olumlu ve olumsuz yansımaları vardır (O'Connor, 2010). Turistler bilgi üretici işleviyle imajı etkileyen kaynaklar olarak değerlendirilirken, turistlerin bilgi üretici işlevleri alanyazında ortak üretici rolleriyle açıklanmaktadır (Buhalis ve Foerste, 2015; Kim ve Fesenmaier, 2017; Molinillo ve diğ. 2018; Arıca, 2019). 
Müşterilerin ortak üreticilik rolünün temelleri ortak üretim anlayışına dayanmaktadır. Ortak üretim etkili ve verimli hizmet geliştirmenin yolu olarak tanımlanmaktadır (Brandsen ve Pestoff, 2006: 494). Geçmişte işletmeden müşteriye üretim, bireylerarası ve işletmeler arası işbirliği biçiminde görülen ortak üretim uygulamalarının (Parks ve diğ., 1981) kapsamı, süreçleri, paydaşları günümüze gelindikçe yaşanan makro ölçekli gelişmeler neticesinde değişim göstermiştir (Arıca ve Kozak, 2018). Günümüzde ortak üretim faaliyetleri müşteriden müşteriye ve müşteriden işletmeye üretim biçiminde de gerçekleşebilmektedir (Rihova ve diğ., 2015; Arıca, 2019). Müşteriler üretimin planlama, üretim, sunum ve değerlendirme aşamalarına katılarak ortak üretici rol edinmektedir (Payne, Storbacka ve Frow, 2008). Buna karşın uygulamada müşterilerin üretim sürecinin değerlendirme aşamasına katılım yoluyla üstlendiği ortak üreticilik rolü yaygın görülmektedir. Rihova, Buhalis, Moital ve Gouthro (2015) bu durumu bilgi ve iletişim teknolojilerinde görülen gelişmelerle ilişkilendirmektedir. Araştırmacılara göre, turistler seyahat esnası ve sonrasında sosyal iletişim ağlarında deneyim çıktılarını paylaşarak ortak üretici rol edinebilmektedir. Benzer şekilde birçok araştırmada turistlerin ortak üreticilik rolünün başat sürükleyicisinin bilgi ve iletişim teknolojilerinde görülen gelişmeler olduğu fikri savunulmaktadır (Buhalis ve Foerste, 2015; Mathis, Kim, Uysal, Sirgy ve Prebensen, 2016; Rihova, Buhalis, Gouthro ve Moital, 2018; Arıca ve Çorbacı, 2019). Li ve Petrick'in (2008) ifade ettiği üzere bilgi ve iletişim teknolojilerinde yaşanan gelişmelerle çevrimiçi ağlar müşterilerin hizmet arama, değerlendirme, satın alma, hizmete ilişkin bilgiler sunduğu alanlar haline gelirken, aynı zamanda bu ağlar paydaşlar arasında işbirliği ve iletişimi sağlayan yapı kazanmıştır. Hem işletmeden müşteriye hem de müşteriden müşteriye iletişimi kolaylaştıran çevrimiçi iletişim ağları müşterilere işletmeler ve benzer ilgi alanına sahip potansiyel müşteriler için bilgi üretici rol yüklemiştir. Daha spesifik olarak, internet kullanımı konusundaki en popüler fenomenlerden biri olan sosyal iletişim ağlarının son yıllarda bilgi paylaşma, bilgi arama ve edinmede giderek daha yaygın kullanılan bir yapıya bürünmesiyle müşterilerin ortak üretici olarak bilgi üretimi işlevi gelişim göstermiştir (Sharda ve Ponnada 2008; Narangajavana ve diğ. 2017).

Sosyal iletişim ağları milyonlarca insanın seyahat deneyimlerini paylaşmasıyla birlikte, turistlerin önemli düzeyde bilgiye sahip olabileceği ve birbirleriyle bilgi alışverişinde bulunabileceği önemli bir kanal haline gelmektedir (Volo 2010; Sun ve diğ. 2015). Turistlerin seyahat esnasında ve sonrasında turistik bölge, işletmeler ve aktivitelere ilişkin sosyal iletişim ağlarında gerçekleştirdiği olumlu ve olumsuz paylaşımlarla ürettiği bilgiler (seyahat fotoğrafları, videolar, duygular, tavsiyeler, fikirler gibi) (O'Connor, 2008) benzer ilgi alanına sahip turistlerin algıları ve karar alma süreçlerinde belirleyici bir etken niteliği kazanırken (Narangajavana ve diğ. 2017), turistik bölge ve işletme yöneticilerinin turistik bölgeye yönelik iyileştirme ve geliştirme girişimlerine yön vermektedir (Wang ve Fesenmaier, 2004; Jacobsen ve Munar, 2012; Zhao ve diğ. 2019). Bilhassa günümüzün başat sosyal iletişim kanalları olan Facebook, Instagram, Twitter gibi sanal toplulukların bir araya geldiği iletişim kanalları ve TripAdvisor, Trivago gibi genel yorum sitelerinde turistlerin aktiviteler veya deneyime ilişkin paylaşımları turistik bölge ve çekiciliklere dair geniş bir bilgi yelpazesi oluşturmaktadır (Munar ve Jacobsen 2014; Molinillo ve diğ. 2018). Pearce'nin (2012: 156) ifadesine göre sosyal iletişim kanalları kullanıcılar için bir 'dijital kütüphane' hüviyeti kazanmaktadır. İşletmeler bu ortamlardaki bilgilerden operasyon ve pazarlama faaliyetlerinde yararlanırken (Yoo ve Gretzel, 2011), bu ortamlardaki bilgiler potansiyel turistlerin tutum, davranış ve karar süreçlerinde temel belirleyiciler haline gelmektedir (Wang, 2011; Munar ve Jacobsen 2014). Sosyal iletişim ağlarındaki gelişimin ve yaygın etkisinin günden güne artması, gerek potansiyel müşteriler gerekse yöneticilerin planlama ve karar alma süreçlerine yön vermesi turistlerin sosyal medya aracılığıyla 
turistik bölgeler ve çekiciliklerle ilgili ürettiği bilginin alanyazında farklı çerçevelerden değerlendirilmesini sağlamıştır.

Dwivedi (2009) Hindistan'ın turistik bölge imajını belirlemeye yönelik gerçekleştirdiği araştırmasında, turistlerin doğal kaynaklar, bölgenin kültürel, tarihsel ve mimari özellikleri üzerine olumlu paylaşımlar yaptıklarını belirlemiştir. Genel ve turistik yatırımlar ise turistlerin olumsuz paylaşımlarına konu olan turistik öğelerdir. Sun, Ryan ve Pan (2015) Yeni Zelenda'yı ziyaret eden turistlerin bölgedeki çekiciliklere ilişkin paylaşımlarını değerlendirmiştir. Turistlerin kentsel ve kırsal kaynaklar, doğal kaynaklar, turistik ve genel yatırımlar, aktiviteler, kültür, politika ve ekonomik faktörler üzerine değerlendirmeler yaptığı tespit edilmiştir. Molinillo, Liebana-Cabanillas, AnayaSanchez ve Buhalis'in (2018) çevrimiçi ağların turistik bölge imajına etkisini incelediği araştırmada, çevrimiçi ağlardaki bilgilere ulaşılabilirliğin turistlerin turistik bölgeye yönelik imaj algılarını ve bölgeyi yeniden ziyaret etme isteğini etkilediği sonucuna ulaşılmıştır. Hao, Xu ve Zhang (2019) sosyal iletişim ağlarında paylaşım yapan gençlerin Kore'ye yönelik imaj algılarının ve tutumlarının doğal çevre, kültür, trafik yoğunluğu, iklim koşulları, konaklama, aktivite ve rekreasyon olanaklarından etkilendiğini belirlemiştir.

Turistlerin işletmeler ve turistik bölgelere yönelik paylaşımlarının bilgi sağlayıcı işleviyle birlikte, paylaşımların niteliği bölge imajının başat belirleyicilerindendir. Kim ve Fesenmaier (2017) turistlerin gezi sonrası sosyal iletişim ağlarında yaptıkları pozitif paylaşımların potansiyel müşterileri olumlu etkilediğini, negatif paylaşımların potansiyel müşterileri olumsuz yönde etkilediğini belirlemiştir. Messner'e göre (2017), sosyal medya platformlarında çevrimiçi olarak yapılan olumlu paylaşımlar potansiyel müşteriler için işletmeyi tercih noktasında belirleyici işlev görürken, olumsuz öneriler işletmeye karşı potansiyel müşterilerin önyargı beslemesine yol açmaktadır. Bu noktada turistlerin sosyal medya aracılığıyla ürettiği bilgi müşteri algıları (Yoo ve Gretzel, 2011), tercih ve karar alma süreçleri (Zeng ve Gerritsen, 2014; Narangajavana ve diğ. 2017), deneyim sürecindeki tutum ve davranışları, turistik bölgelerin tanıtımı, bölge ve işletmelerin marka değeri (Tussyadiah ve Fesenmaier 2008; Sun ve diğ. 2015) ve rekabet gücünü etkileyebilmektedir (Messner, 2017).

\section{Araştırmanın Yöntemi}

\subsection{Araştırmanın Amacı ve Kapsamı}

Araştırmanın amacı, turistlerin Adıyaman'daki çekiciliklere yönelik TripAdvisor.com sitesinde yaptığı paylaşımlarla ürettiği bilgilerin değerlendirilmesidir. Araştırmanın kapsamını, Adıyaman'daki turistik çekiciliklere yönelik TripAdvisor sitesinde yapılan yorumlar oluşturmaktadır. Bu çerçevede Adıyaman'da bulunan ve TripAdvisor'daki yorumlara konu olan toplamda dokuz turistik çekiciliğe yönelik 754 yorum yapıldığı belirlenmiş ve paylaşımlar nitel analiz yöntemiyle değerlendirilmiştir.

\subsection{Verilerin Toplanması}

Araştırmada TripAdvisor website'sinde (www.tripadvisor.com) yer alan, Adıyaman'daki turistik çekicilere yönelik yorumlar değerlendirilmiştir. TripAdvisor dünyanın en büyük çevrimiçi seyahat topluluğu ve kullanıcılar tarafından oluşturulan içeriklerin incelendiği en popüler web sitelerinden biridir (O'Connor, 2008). TripAdvisor sitesinde 08.06.201915.06.2019 tarihleri arasında yapılan incelemeler neticesinde, Adıyaman'daki turistik çekiciliklere yönelik 754 yorum belirlenmiştir. Yorumlara konu olan Adıyaman'daki turistik çekicilikler şu şekildedir: Nemrut Dağı Ören Yeri, Cendere Köprüsü, Karakuş 
Tümülüsü, Perre Antik Kenti, Adıyaman Müzesi, Su Gözü Mesire Alanı, Safvan Bin Muattal Türbesi, Gölbaşı Gölleri Tabiat Parkı ve Sofraz Tümülüs Mezarları. Gerekli inceleme sayısını sağlamak ve araştırma örneklem büyüklüğüne karar verilmesinde alanyazındaki ilgili çalışmaların örneklem büyüklükleri değerlendirilmiştir. Örneğin, Dwivedi (2009) 100 paylaşımı incelerken, Volo (2010) 246 paylaşım üzerinden, Wang (2011) 329 paylaşımı kullanarak inceleme gerçekleştirmiştir. Sun, Ryan ve Pan (2015) 409 yorumu analiz ederken, Brochado, Rita, Oliveira ve Oliveira (2019) 1.776 yorumu değerlendirmiştir. $\mathrm{Bu}$ bağlamda çalışma kapsamında incelenen örneklemin alanyazında benzer çalışmalarda incelenen örneklem ortalamalarına yakın olduğu görülmektedir.

\subsection{Verilerin Analizi}

Metinsel verileri işlemek için hem niteliksel hem de niceliksel analizler kullanılabilmektedir (Zhang ve Cole, 2016). Mevcut araştırmada veriler içerik analizi yöntemiyle anlamlı hale getirilirken, sınıflandırılan verilerin betimlenmesinde tanımlayıcı analiz yönetiminden faydalanılmıştır. İçerik analizi ve tanımlayıcı analizler, hızla büyüyen web iletişimini yorumlamak için etkili bir yöntem olarak önem kazanmaktadır. Araştırmada TripAdvisor sitesindeki 754 yorum üzerinden analizler gerçekleştirilmiştir. Bu kapsamda öncelikle, veriler derlenmiş ardından derlenen veriler sayısallaştırılmış ve benzer yorumlar gruplandırılarak değerlendirilmiştir. Yorumlar farklı dillerde gerçekleştirildiğinden (Bkz: Tablo 2) verilerin derlenmesi sürecinde yabancı dilde yapılan yorumlar Türkçeye çevrilerek analiz edilmiştir. Mevcut araştırmada verilerin gruplandırılmasında Beerli ve Martin (2004) tarafından geliştirilen, Dwivedi (2009) ve Sun, Ryan ve Pan (2015) tarafından sosyal iletişim ağlarındaki paylaşımların değerlendirilmesinde kullanılan yapıdan faydalanılmıştır. Bu yapı dokuz kategoriden oluşurken, kategoriler şöyledir: (i) doğal kaynaklar, (ii) genel altyapı, (iii) turistik altyapı, (iv) turistik boş zaman ve rekreasyon, (v) kültür, tarih ve mimari, (vi) politik ve ekonomik faktörler, (vii) doğal çevre, (viii) sosyal çevre ve (ix) mekan atmosferi.

\section{Analiz ve Bulgular}

Araştırma kapsamında Adıyaman'ı seyahat eden turistlerin ziyaret ettikleri turistik çekiciliklere yönelik genel bakış puanları, turistlerin uyrukları, yorum yaparken kullandıkları teknolojik araçlar, tatmin durumları, bölgeyi tavsiye etme niyetleri ve yorumlara konu olan turistik çekiciliklerin özellikleri değerlendirilmiştir. Araştırma kapsamında analize konu olan temel unsurlar ve bulgular Şekil 1'de özetlenmektedir. 
Şekil 1: Araştırma Elde Edilen Bulguların Kavram Haritası

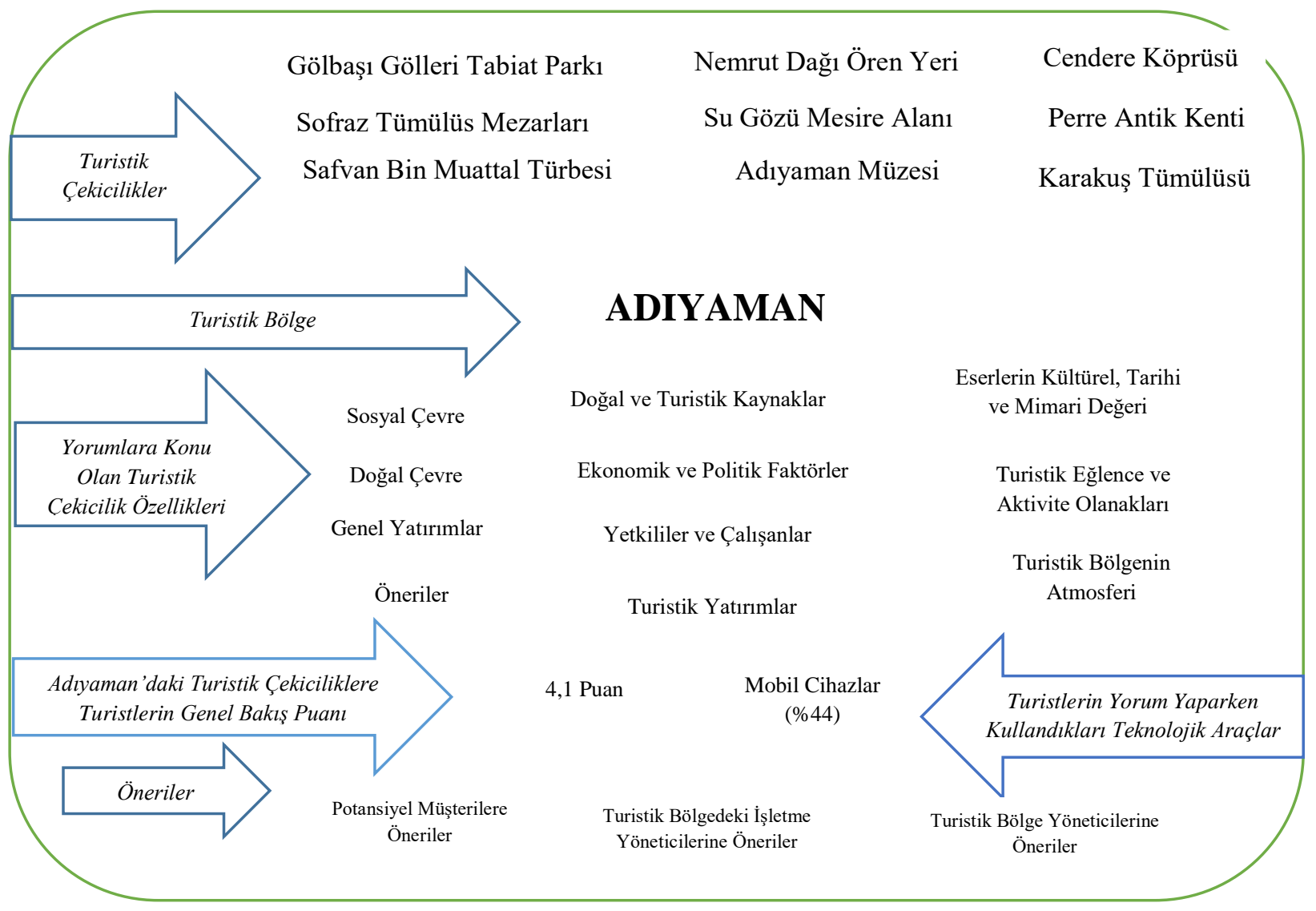

Araştırmada Adıyaman'daki dokuz turistik çekiciliğe yönelik yorumlar değerlendirilmiştir. Turistik çekiciliklerin yorumlara konu olan özellikleri 11 farklı kategoride toplanmıştır. TripAdvisor'da Adıyaman'daki turistik çekiciliklere yönelik turistlerin yaptıkları değerlendirme puanlarının ortalaması 4,1'dir. Bir diğer bulguya göre, turistlerin yorumlamalarda günümüze gelindikçe mobil cihazlardan faydalanma düzeyleri artmaktadır. Bununla birlikte turistlerin yaptıkları paylaşım ve yorumlarla potansiyel müşteriler, bölgedeki işletme yöneticileri ve turistik bölge yöneticilerine öneriler sunduğu bulgusuna ulaşılmıştır.

Tablo 1: Turistlerin Turistik Çekiciliklere Genel Bakış Açısı

\begin{tabular}{|l|c|c|c|c|c|c|c|}
\hline $\begin{array}{l}\text { Genel Bakış Açısı/ } \\
\text { Turistik Çekicilikler }\end{array}$ & Mükemmel & Çok İyi & Ortalama & Kötü & Berbat & Toplam & $\begin{array}{c}\text { Toplam } \\
\text { Puan }\end{array}$ \\
\hline $\begin{array}{l}\text { Nemrut Dağı Ören } \\
\text { Yeri }\end{array}$ & 371 & 65 & 18 & 5 & 2 & 461 & 4,5 \\
\hline Cendere Köprüsü & 80 & 50 & 7 & 1 & 0 & 138 & 4,5 \\
\hline Karakuş Tümülüs & 11 & 29 & 8 & 1 & 0 & 49 & 4,0 \\
\hline Perre Antik Kenti & 19 & 18 & 9 & 0 & 0 & 46 & 4,0 \\
\hline Adıyaman Müzesi & 9 & 6 & 9 & 4 & 2 & 30 & 3,5 \\
\hline $\begin{array}{l}\text { Su Gözü Mesire } \\
\text { Alanı }\end{array}$ & 5 & 5 & 2 & 0 & 0 & 12 & 4,0 \\
\hline
\end{tabular}


Tablo 1'in devamı

\begin{tabular}{|l|c|c|c|c|c|c|c|}
\hline $\begin{array}{l}\text { Safvan Bin Muattal } \\
\text { Türbesi }\end{array}$ & 5 & 6 & 1 & 0 & 0 & 12 & 4,5 \\
\hline $\begin{array}{l}\text { Gölbaşı Gölleri } \\
\text { Tabiat Parkı }\end{array}$ & 1 & 1 & 1 & 0 & 0 & 3 & 4,0 \\
\hline $\begin{array}{l}\text { Sofraz Tümülüs } \\
\text { Mezarları }\end{array}$ & 0 & 2 & 0 & 0 & 1 & 3 & 4,0 \\
\hline Toplam & $\begin{array}{c}\mathbf{5 0 1} \\
(\mathbf{\% 6 6 )}\end{array}$ & $\begin{array}{c}\mathbf{1 8 2} \\
\mathbf{( \% 2 4 )}\end{array}$ & $\begin{array}{c}\mathbf{5 5} \\
\mathbf{( \% 7 )}\end{array}$ & $\begin{array}{c}\mathbf{1 1} \\
\mathbf{( \% 2 )}\end{array}$ & $\begin{array}{c}\mathbf{5} \\
\mathbf{( \% 1 )}\end{array}$ & $\begin{array}{c}\mathbf{7 5 4} \\
\mathbf{( \% 1 0 0 )}\end{array}$ & $\mathbf{4 , 1}$ \\
\hline
\end{tabular}

Adıyaman'daki turistik çekiciliklere yönelik turistlerin genel bakış açısına dair bulgular incelendiğinde (Bkz: Tablo 1), turistlerin Adıyaman'daki turistik çekiciliklere genel bakış açısının olumlu olduğu görülmektedir. Toplamda Nemrut Dağı Milli Parkı, Cendere Köprüsü ve Safvan Bin Muattal Türbesi genel bakışın en olumlu bakışın olduğu turistik eserler iken, Adıyaman Müzesi olumlu bakış açısının en düşük değer aldığı turistik eserdir.

Tablo 2: Paylaşımlara Göre Turistlerin Memnuniyet Durumları ve Bölgeyi Tavsiye Etme Niyetleri

\begin{tabular}{|c|c|c|}
\hline Memnuniyet Durumu ve Tavsiye Etme Niyeti & Frekans & Yüzde (\%) \\
\hline \multicolumn{3}{|c|}{ Memnuniyet Durumu } \\
\hline Memnunum & 725 & 96,2 \\
\hline Memnun Değilim & 27 & 3,6 \\
\hline Kısmen Memnunum & 2 & 0,2 \\
\hline \multicolumn{3}{|c|}{ Tavsiye Etme Niyeti } \\
\hline Tavsiye Ederim & 725 & 96,2 \\
\hline Tavsiye Etmem & 21 & 2,8 \\
\hline Kararsızım & 8 & 1,1 \\
\hline Toplam & 754 & 100 \\
\hline
\end{tabular}

Turistlerin seyahatlerinden memnuniyet durumları ve seyahati tavsiye etme niyetleri incelendiğinde; genel itibariyle memnun oldukları ve seyahati tavsiye etme eğiliminde oldukları görülmektedir. Turistler tesisleşme, çevre düzenlemesi eksiklikleri ve yorucu seyahatlere rağmen bölgedeki çekiciliklerin görülmeye değer olduğuna işaret etmektedir.

Tablo 3: Turistlerin Uyrukları ve Yorum Yaptıkları Diller

\begin{tabular}{|c|c|c|c|c|c|}
\hline Turistlerin Uyrukları & Frekans & $\begin{array}{c}\text { Yüzde } \\
(\%)\end{array}$ & Yorum Yapılan Diller & Frekans & $\begin{array}{l}\text { Yüzde } \\
\text { (\%) }\end{array}$ \\
\hline Türkiye & 480 & 63,7 & Türkçe & 454 & 60,2 \\
\hline $\mathrm{ABD}$ & 43 & 5,7 & İngilizce & 192 & 25,5 \\
\hline Avustralya & 23 & 3,1 & İtalyanca & 21 & 2,8 \\
\hline İngiltere & 23 & 3,1 & Çince & 17 & 2,3 \\
\hline İtalya & 19 & 2,5 & Japonca & 16 & 2,1 \\
\hline Japonya & 12 & 1,6 & İspanyolca & 11 & 1,5 \\
\hline Hollanda & 12 & 1,6 & Almanca & 11 & 1,5 \\
\hline Çin & 10 & 1,3 & Rusça & 10 & 1,3 \\
\hline Belirtilmeyen & 29 & 3,8 & Diğer & 22 & 3,0 \\
\hline Diğer & 103 & 13,6 & \multirow{2}{*}{ Toplam } & \multirow{2}{*}{754} & \multirow{2}{*}{100} \\
\hline Toplam & 754 & 100 & & & \\
\hline
\end{tabular}


Adıyaman'a seyahat eden turistlerin uyrukları ve yorum yaptıkları dillere ilişkin bulgular, turistlerin yarısından fazlasının $(\% 63,7)$ Türkiye vatandaşı olduğunu göstermektedir. Ayrıca Avrupa, Amerika, Asya ve Afrika kıtasındaki ülkelerden Adıyaman'a seyahat gerçekleşmektedir. Yorum yapılan dillere ait bulgular incelendiğinde, turistlerin Türkçe ve İngilizce başta olmak üzere (\%86) birçok farklı dillerde yorum yaptığı görülmektedir. Bulgular, Adıyaman'da farklı kıtalardan ve ülkelerden turist ağırlandığını göstermektedir.

Tablo 4: Turistlerin Yıllara Göre Yorum Yaparken Kullandıkları Teknolojik Araçlar

\begin{tabular}{|c|c|c|c|c|c|c|c|c|c|c|c|}
\hline $\begin{array}{l}\text { Teknolojik } \\
\text { Araçlar }\end{array}$ & 2019 & 2018 & 2017 & 2016 & 2015 & 2014 & 2013 & 2012 & 2011 & $\begin{array}{l}2010- \\
2005\end{array}$ & Toplam \\
\hline $\begin{array}{l}\text { Mobil } \\
\text { Cihazlar }\end{array}$ & 49 & 106 & 61 & 58 & 35 & 18 & 0 & 1 & 0 & 1 & $\begin{array}{c}329 \\
(\% 43,6)\end{array}$ \\
\hline $\begin{array}{l}\text { Diğer } \\
\text { Cihazlar }\end{array}$ & 16 & 48 & 48 & 33 & 100 & 80 & 45 & 29 & 10 & 16 & $\begin{array}{c}425 \\
(\% 56,4)\end{array}$ \\
\hline Toplam & 65 & 154 & 109 & 91 & 135 & 98 & 45 & 30 & 10 & 17 & 754 \\
\hline
\end{tabular}

Turistlerin yorum yaparken kullandıkları araçlar taşınabilir mobil cihazlar ve taşınamayan teknolojik cihazlardan oluşmaktadır. Bulgulara göre, turistlerin taşınabilir mobil cihazlarla yorum yapma oranının günden güne gelişim gösterdiği görülmektedir. Araştırma bulguları, günümüzde yaşamın merkezinde yer edinen mobil cihazlardan bilgi paylaşma ve ediniminde gelecekte daha fazla yararlanılacağına işaret etmektedir.

\section{Tablo 5: Adıyaman'daki Turistik Çekiciliklerin Yorumlara Konu Olan Özellikleri}

\begin{tabular}{|c|c|}
\hline $\begin{array}{l}\text { 1. Doğal ve } \\
\text { Turistik } \\
\text { Kaynaklar }\end{array}$ & $\begin{array}{l}\text { Turistik Çekicilikler (276)*: turistik çekicilikler çeşitli ve mükemmel (124), turistik } \\
\text { çekicilikler sıradan (51), turistik eserler korunmuş (35), turistik eserlerin tarihi muhteşem } \\
\text { (30), turistik eserler tahrip olmuş (19), turistik eserler bakımsız (17) } \\
\text { Turistik Alanlardaki İklimsel Özellikler (162): soğuk (119), rüzgârlı (27), sıcak (10), } \\
\text { bulutlu (6) }\end{array}$ \\
\hline & $\begin{array}{l}\text { Bölgeye Ulaşım Yolları ve Kalitesi (3): havaalanı ve uçuş sayısı yeterli (2), havaalanı ve } \\
\text { uçuş sayısı yetersiz (1) } \\
\text { Şehir Içi Taşıma Olanakları (22): yeterli (20), yetersiz (2) } \\
\text { Şehir İçi Yönlendirme Tabelaları (4): yeterli (1), yetersiz (3) }\end{array}$ \\
\hline & 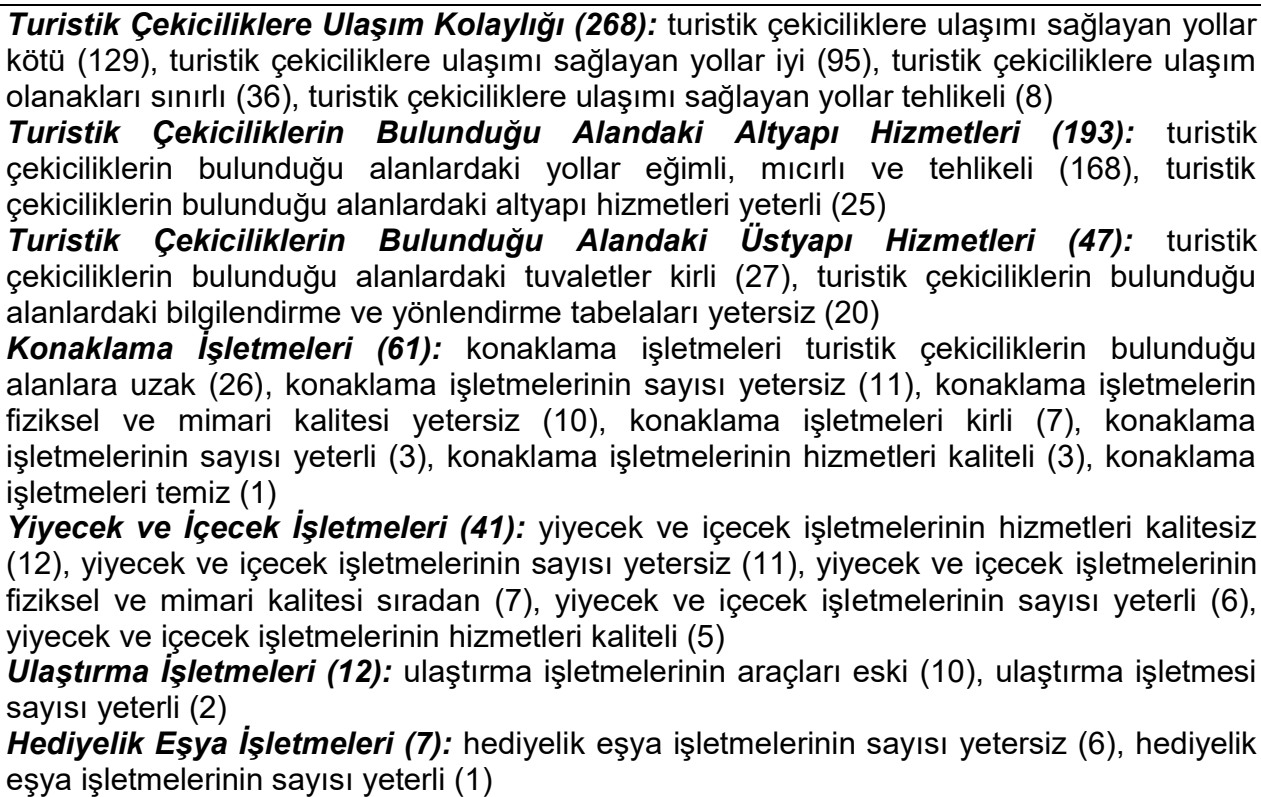 \\
\hline
\end{tabular}


Tablo 5'in devamı

\begin{tabular}{|c|c|}
\hline $\begin{array}{l}\text { 4. Turistik } \\
\text { Eğlence ve } \\
\text { Aktivite } \\
\text { Olanakları }\end{array}$ & $\begin{array}{l}\text { Eğlence ve Aktivite Olanakları (48): eğlence ve aktivite alanları bulunmamakta (21), } \\
\text { piknik alanları bulunmakta (17), yüzme alanları bulunmakta (10) }\end{array}$ \\
\hline $\begin{array}{l}\text { 5. Turistik } \\
\text { Eserlerin } \\
\text { Kültürel, Tarihi } \\
\text { ve Mimari Değeri }\end{array}$ & $\begin{array}{l}\text { Külttür (45): müze sıradan (17), bölgede farklı medeniyetlere ait kültürel çeşitliliği } \\
\text { gözlemleyebiliyorsunuz (12), bölgede farklı medeniyetlere ait gelenekleri } \\
\text { gözlemleyebiliyorsunuz (8), bölgede farklı medeniyetlere ait dinsel çeşitliliği } \\
\text { gözlemleyebiliyorsunuz (8) } \\
\text { Gastronomi (6): yiyecek ve içecekler sıradan ve seçenekler sınırlı (8), yiyecek ve } \\
\text { içecekler geleneksel ve çeşitli (6) } \\
\text { Tarihi yapılar (426): eserler tarih harikası (289), eserler tarihi yaşatıyor (113), bölgede } \\
\text { birçok tarihi eser bulunmakta (24) } \\
\text { Eserlerin mimarisi (268): eserlerin mimarisi mükemmel (232), bölgede anıt mezarlar } \\
\text { bulunmakta (18), bölgede mimari harikası sütunlar bulunmakta (15), eserlerde mimari ve } \\
\text { astronomik özellikler bir arada bulunmakta (3) }\end{array}$ \\
\hline $\begin{array}{l}\text { 6. Ekonomik ve } \\
\text { Politik Faktörler }\end{array}$ & $\begin{array}{l}\text { Fiyatlar (63): fiyatlar pahalı (39), fiyatlar uygun (24) } \\
\text { Güvenlik (9): turistik bölge güvenli (7), turistik bölge güvensiz (2) }\end{array}$ \\
\hline 7. Doğal Çevre & $\begin{array}{l}\text { Turistik çekiciliklerin manzarası mükemmel (319) } \\
\text { Turistik çekiciliklerin bulunduğu alanın doğası mükemmel (102) } \\
\text { Turistik çekicilik alanlarının kalabalık olma durumu (30): kalabalık (17), sakin (13) } \\
\text { Doğal çevrenin kirli/temiz olma durumu (28): doğal çevre kirli (18), doğal çevre temiz } \\
\text { (10) } \\
\text { Havanın kirli/temiz olma durumu (25): hava temiz (22), hava kirli (3) }\end{array}$ \\
\hline 8. Sosyal Çevre & $\begin{array}{l}\text { Yerel halk turistik eserlere karşı duyarsız (15) } \\
\text { Yerel halk turistlere karşı yardımsever (14) } \\
\text { Yerel halk turistlere karşı misafirperver (8) } \\
\text { Yerel halkın yabancı dil becerileri yetersiz (7) }\end{array}$ \\
\hline $\begin{array}{l}\text { 9.Turistik } \\
\text { Bölgenin } \\
\text { Atmosferi }\end{array}$ & $\begin{array}{l}\text { Etkileyici (119), Eşsiz (96), Göz alıcı (76), İlgi çekici (70), Harika (62), Keyif verici (51), } \\
\text { Hayret verici (34), Sıkııı (35), Rahatlatıcı (24), Huzur verici (24), Şöhretli (21), Olağanüstü } \\
\text { (20), Ailelere yönelik turistik bölge (18), Gizemli (16), Egzotik (9) }\end{array}$ \\
\hline $\begin{array}{l}\text { 10. Yetkililer ve } \\
\text { Çalışanlar }\end{array}$ & $\begin{array}{l}\text { Yetkililer (43): yerel yönetim turistik eserlere karşı ilgisiz (33), ulusal yönetimler turistik } \\
\text { eserlere karşı ilgisiz (8), yerel yönetim turistik eserlere karşı ilgili (2) } \\
\text { Çalışanlar (76): turistik işletme çalışanları cana yakın ve yardımsever (40), turistik işletme } \\
\text { çalışanlarının yetkinlikleri ve iletişim becerileri zayıf (23), turistik işletme çalışanlarının dil } \\
\text { becerileri zayıf (4), turistik işletme çalışanları kaba (3), turistik işletme çalışanları } \\
\text { profesyonel değil (2), rehberler bölgeye dair yeterli bilgiye sahip değil (2), turistik işletme } \\
\text { çalışanları duyarsız (2) }\end{array}$ \\
\hline 11. Öneriler & 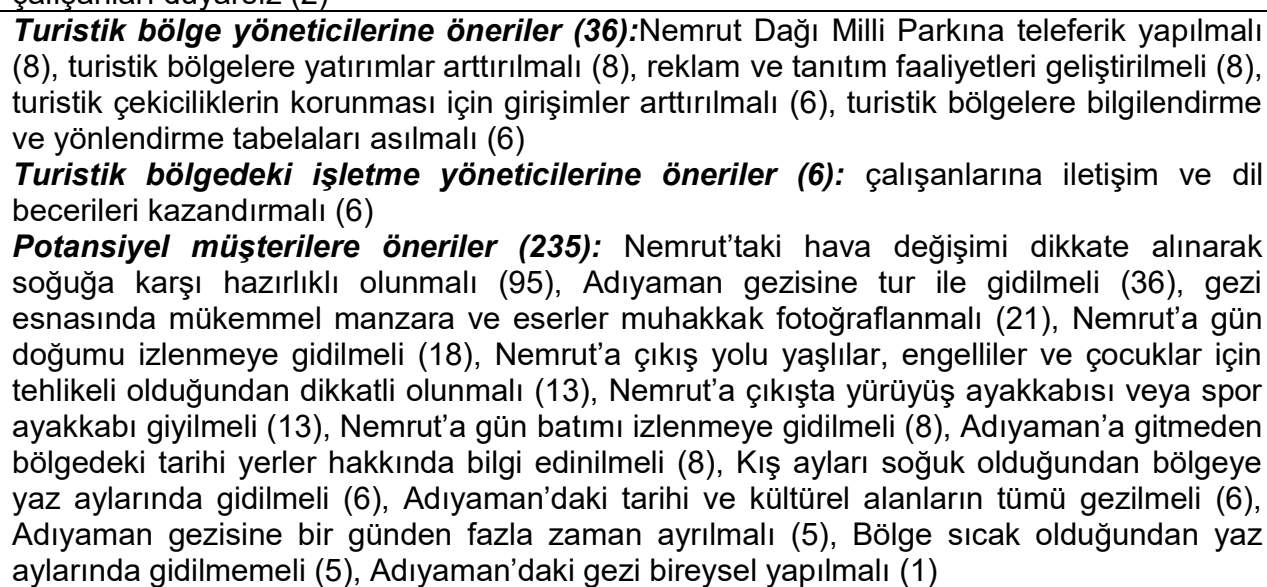 \\
\hline
\end{tabular}

*parantez içindeki rakamlar ifadelere ait frekansları açıklamaktadır. 
Turistlerin Adıyaman'daki çekiciliklerin özelliklerine yönelik yaptıkları paylaşımlar ve yorumlar değerlendirildiğinde, 11 farklı kategori belirlenmiştir. Bunlar; (i) doğal ve turistik kaynaklar, (ii) genel yatırımlar, (iii) turistik yatırımlar, (iv) turistik eğlence ve aktivite olanakları, (v) eserlerin kültürel, tarihi ve mimari değeri (vi) ekonomik ve politik faktörler, (vii) doğal çevre, (viii) sosyal çevre, (ix) turistik bölgenin atmosferi, (x) yetkililer ve çalışanlar ve (xi) önerileridir.

(i) Doğal ve turistik kaynaklar arasında turistik bölgedeki çekiciliklerin çeşitliliğiyle birlikte, bölgedeki iklimsel özellikler turistler tarafından değerlendirilmiştir. Turistler doğal ve turistik kaynakları çeşitli ve bozulmamış olarak algılarken, havanın ise soğuk olduğunu ifade etmektedir. Turistlerin Adıyaman'daki doğal ve turistik kaynaklara bakış açısı olumludur. Buna karşın havanın soğuk olarak nitelendirilmesi Nemrut Dağı Ören Yeriyle yakından ilişkilidir. Nemrut Dağına seyahat eden turistler, yüksek rakıma çıkıldığından bölgede sıcaklık değişiminin yaşandığını ve bölgede sıcaklık değerlerinin merkezdeki sıcaklık değerlerinden oldukça farklı olduğuna dikkat çekmektedir.

Ingiltere, 2017 (Adıyaman):...Adıyaman birçok turistik ve tarihi eserin olduğu bir yer. Burada tarihi yaşıyorsunuz. Nemrut'a çıkarken tüm eserleri görebilirsiniz.

Türkiye, 2017 (Nemrut Dağı):... Anıt heykeller güzel korunmuş.

Türkiye, 2017 (Nemrut Dağı): Heykeller çok tahrip olmuş... Bu eserler başka ülkelerde olsa nasıl koruma altına alınır ve değer verilirdi düşünemiyorum.

Türkiye, 2017 (Nemrut Dağı): Adıyaman sıcaklık 35 derece iken Nemrut dağında donduk ve rüzgârdan dolayı 2150 metre dağı zor yürüdük. Kaban falan giydik ancak yetersiz kaldı.

Çin, 2015 (Nemrut Dağı): ...dağ 2.000 metreden yüksek, dağın tepesindeki rüzgâr oldukça yüksek, güneş olmasına rağmen sıcaklık düşük...

Türkiye, 2014 (Perre Antik Kenti, Karakuş Tümülüs, Cendere Köprüsü): ... MÖ 1 yüzyıldan kalma Komagene ailesine ait anıt mezarlar topluluğu. Mezar anıtları çok yıpranmış. Bir adet kartal anıtı az yıpranmış olarak duruyor. Aslan ve boğa sütunları ise çok yıpranmış. Cendere ise muhteşemliğiyle tarihe meydan okuyor.

(ii) Genel yatırımlar turistlerin sosyal medyadaki paylaşım ve yorumlarında yer verdikleri bir diğer kategori olmuştur. Bu bağlamda, havaalanının yeterliliği, uçuş sayısı, şehir içi taşıma olanakları ve şehir içi yönlendirme tabelaları turistlerin değindikleri başlıca konular olmuştur.

Türkiye, 2018 (Adıyaman):..bölgedeki havaalanı yeterli ama düzenlenen uçuşlar yetersiz.

Türkiye, 2017 (Adıyaman): ...şehir içi taşıma gelişmiş. Perre'ye bile belediye otobüsleriyle gidebiliyorsunuz.

Türkiye, 2015 (Adıyaman):...şehir merkezinden turistik bölgelere nasıl ulaşacağımıza dair bir tabela bile görmedik. Yollarda kaybolduk.

(iii) Turistik yatırımlar sosyal medya paylaşımlarında en popüler konulardan biri olmuştur. Turistik çekiciliklere erişim kolaylığı ve turistik eserlerin bulunduğu alandaki altyapı ve üstyapı yatırımları paylaşımlara konu olmuştur.

Türkiye, 2018 (Adıyaman):...turistik bölgelerin bir kısmına ulaşım kolayken, özellikle Nemrut'a ulaşım yolu çok kötü, virajlı ve tehlikeli.

İtalya, 2018 (Nemrut Dağı): Bu son kısım uzun, oldukça dik ve kısmen rahatsız edicidir: başlangıçta iyi döşenmiş taşlar ve hafif eğimli yol var; ancak yolun son 
kısmı çok düzensiz ve kayalık bir tabana sahip. Fiziksel durumu elverişli uygun olmayan insanların buraya çıkması zor. Nemrut'un girişinde modern bir kafe ve bir restoran var; restoran geniş ve hoş bir terasa sahip.

Türkiye, 2018 (Cendere Köprüsü): Köprüden çocuklar filan düşebilir korkuluk yok. Ayrıca etrafta gelenin oturabileceği gölgelik yok. Ufak bir büfe ihtiyaçlarınıza cevap vermeye çalışıyor.

Türkiye, 2017 (Nemrut Dağı, Adıyaman): Buraya gitmek için epey yol gittik. Bence gittiğimize değmez. Her şeyden önce konaklama yerleri güzel değil...

Macaristan, 2017 (Adıyaman): Bölgede otel ve restoran sayısı az.

Amerika, 2015 (Nemrut Dağı): Dağın tepesine yürüyüş kolay ve istediğinizde dinlenebileceğiniz çok sayıda bank var.

Amerika, 2008 (Adıyaman): Bölgedeki oteller çok kötü, oteldeki yiyecek ve içecekler dâhil her şey kötü...

(iv) Turistik eğlence ve aktivite olanakları paylaşımlarda sınılı düzeyde yer almıştır. Bilhassa turistik eğlence ve aktivite imkânlarının yetersizliğine dair paylaşımların varlığı dikkat çekmektedir.

Türkiye, 2018 (Adıyaman):...Adıyaman'daki eğlence olanakları yeterince gelişmemiş. Zaman geçirelim diyeceğiniz doğru dürüst bir eğlence alanı yok...

İngilizce, 2018 (Gölbaşı): Gölün etrafında piknik ve yürüyüş yapabilirsiniz. Çocuklar için oyun alanları var...

(v) Turistler tarafından sıkça değerlendirilen bir diğer kategori turistik bölgedeki eserlerin kültürel, tarihi ve mimari değeridir. Bölgedeki tarihsel ve kültürel eserleri oluşturan heykeller, sütunlar, nekropoller, antik ve mimari kalıntılar turistler tarafından görülmeye değer ve mükemmel mimari özelliklere sahip olarak açıklanmıştır.

Türkiye, 2019 (Adıyaman): Bölgenin çok özel bir mimarisi var... öncelikle tarihi değeri yüksek ama bir o kadar da mimari estetiği olan eserler var.

Türkiye, 2018 (Nemrut Dağı): Nemrut Adıyaman'ın en önemli ve en muhteşem görülmesi gerek en önemli yeri. 2150 metre yüksekliğindeki Nemrut Dağı, 1987 yılında UNESCO Dünya Mirasları Listesi'ne girmiş. Nemrut Dağının en tepesinde yani $2150 \mathrm{mt}$ yükseklikte bulunan antik mezar, anıtsal heykeller, mimari kalıntıları ile akıllara durgunluk veriyor.

Türkiye, 2018 (Cendere Köprüsü): Antik Roma mimarisinin muhteşem bir anıtsal örneğidir....120 metre uzunluğunda olan köprünün en ilginç mimari özelliği harç kullanılmadan yapılmış olmasıdır. Köprü, her iki tarafından rampa biçiminde yükselerek orta kısımda yarım ay şeklini alarak birleşmektedir. Bu özellik köprünün hem statik olarak dayanıklıı̆ıını artırmakta hem de köprüye anıtsal bir görünüm kazandırmaktadır.

Nepal, 2017 (Sofraz Tümülüs Mezarları): Eski hamamlar, kale ve topluluk izleri... Antik dünya inanılmaz işçilikle aktarılmış.

Türkiye, 2016 (Cendere Köprüsü): Cendere Köprüsü bir kanyondan akan nehrin üzerine harç kullanılmadan kilit taşı yöntemiyle yapılmış harika bir eser... Buram buram tarih kokan Adıyaman'ın Kahta ilçesinde yıllara dayanabilmiş güzel bir yapı.

(vi) Turistler seyahat bloglarında ekonomik ve politik faktörlere yönelik paylaşımlarda bulunmuştur. Bu bağlamda fiyatlar ve turistik bölgenin güvenliği konusuna dair paylaşımlarda bulunmuşlardır. Özellikle turistik bölgenin güvenli olduğunu ifade 
eden yabancı turistler, yurtdışında bilinenin aksine bölgenin savaş ortamında olmadığına vurgu yapmaktadır.

Fransa, 2018 (Adıyaman): Adıyaman muhtemelen Suriye'ye olan yakınlığından dolayı pek dikkat çekmiyor, ancak burayı seyahat ettiğiniz zaman kesinlikle hiçbir tehlike altında bulunmuyorsunuz.

İspanya, 2018: (Adıyaman) ...bölgeye düzenlenen tur kapsamındaki aktiviteler sınırlı olmasına karşın maliyet bizim için çok yüksek.

(vii) Doğal çevre birçok paylaşım ve yoruma olumlu yönleriyle konu olan bir diğer kategoridir. Turistler manzara ve doğanın büyüleyici güzelliği, havanın temiz olması, doğal çevrenin kirli ve kalabalık olması konularına dikkat çekmiştir.

İtalya, 2018 (Adıyaman): Bu zamanlarda çok fazla insanın varlığı sitenin mistik atmosferini bozabilir...;... FIrat nehri ve yapay gölü kadar uzanan, tüm bölgeyi kapsayan muazzam panoramik manzara etkileyicidir.

Macaristan, 2015 (Adıyaman): ... havası temiz.. Öte yandan manzara nefes kesici! Özel bitki örtüsü ve muhteşem manzaralı büyük dağlar.... ... Görünümü benzersiz...

Türkiye, 2014 (Adıyaman): Muazzam güzellikteki doğa görülmeye değer. Onun yanı sıra kuş sever bir doğacı iseniz, Nemrut' un eteklerinde görebileceğiniz Kuyrukkakan türleri, Kulaklı toygar, Kar Serçesi gibi türleri de burada...

Japonya, 2009 (Nemrut Dağı):...Sabah güneşini izlemek için mükemmel, manzara gerçekten harika.

(viii) Birçok turist bölgedeki sosyal çevre konusundaki paylaşımlarında yerel halkın yardımseverliği ve misafirperverliğiyle birlikte, turistik çekiciliklere karşı duyarsız olmalarına yer vermiştir.

Türkiye, 2017 (Adıyaman):...En çok etkilendiğim nokta ise Adıyaman halkının yardımseverliği ve misafirperverliği oldu...

Türkiye, 2017 (Cendere köprüsü): gerçekten çok güzel ama biz gittiğimizde ortam çok kötüydü... Yerel halk duyarsı, dereye pikniğe gelmiş. Etraf çok pis.

(ix) Turistik bölgenin atmosferi turistlerin paylaşımlarında en fazla yer verdiği kategoriler arasında yer almaktadır. Turistlerin büyük bir bölümü bölgenin etkileyici, eşsiz, göz alıcı atmosferine dikkat çekerken, çok az sayıda turist bölgedeki atmosferi sıkıcı ve sıradan bulduklarına dair paylaşımda bulunmuştur.

Ingiltere, 2017:...Tüm deneyim ve atmosfer çok etkileyiciydi.

Bulgaristan, 2015: Büyüleyici, mistik ve olağanüstü bir atmosfer.

Türkiye, 2014: ....atmosfer insanı rahatlatıyordu. Çok etkilendim.

Fransa, 2014: .........sıkıcı bir yer.

(x) Yetkililer ve çalışanlara dair paylaşım ve yorumlar olumlu ve olumsuz biçimde olmasında karşın genel itibariyle olumsuzlukları ön plana çıkaran değerlendirmelerin yapıldığı görülmektedir. Bilhassa yetkililerin turistik çekiciliklere karşı ilgisizliği, işletme çalışanlarının yetenek ve yetkinliklerinin yeterli düzeyde olmadığına dikkat çekilmektedir. Aynı zamanda turistlerin bir kısmı çalışanları cana yakın ve yardımsever olarak değerlendirmektedir.

Türkiye, 2018: ...Oradaki muhteşem eserler ne yazık ki sahipsiz kalmış ve acil daha fazla korumaya intiyaçları var... 
Türkiye, 2018: Insan dışına biraz canlılık katar, düzgün bir tabela koyar, insanları buraya çekecek şeyler yapar. Çalışanlarda ilgisiz. Yetkililerin buraya acil müdahale etmeleri lazım..

Çin, 2018: Nemrut Dağındaki personellerin dil becerileri yetersiz olmasına rağmen, tümü ailemize ve bize çok kibar ve cana yakın davrandı.

Türkiye, 2014: ...dünyanın en önemli değerlerinin bulunduğu Nemrut gerçek anlamda kaderine terk edilmiş durumda... çok yazık... çalışanlarla iletişim kuramıyorsunuz, ilgisizler.

(xi) Turistler turistik bölgenin özelliklerine dair yukarıda ifade edilen kategorilere ilişkin tanımlayıcı bilgiler üretirken, öte yandan turistik bölge yöneticilerine, turistik bölgedeki işletme yöneticilerine ve benzer ilgi alanına sahip potansiyel müşterilere yönlendirici bilgiler (öneriler) sunmuştur. Turistik bölge yöneticilerine dair öneriler, turistik alt ve üstyapının geliştirilmesi odağında kümelenirken, işletmelere yönelik öneriler çalışanlarının iletişim ve dil becerilerinin geliştirilmesi çerçevesindedir. Bununla birlikte turistler benzer ilgi alanına sahip potansiyel müşterilere deneyim kalitelerini geliştirmeleri bağlamında tavsiyelerde bulunmaktadır.

Türkiye, 2017: Mutlaka tur ile katılmanızı tavsiye ederim çünkü gezilecek yerler arası mesafe uzun... Mutlaka rahat yürüyüş ayakkabısı, uzun kollu kalın kıyafetler alınız, yazın bile çok soğuk üşürsünüz. Atıştırmalık bulundurunuz, kafeteryadan veya servislerden iner inmez köşede su almayı unutmayınız başka yerde bulamazsınız.

Türkiye, 2017 (Nemrut Dağı:...Buraya bir teleferik yada ulaşmak için uygun bişeyler yapılmalı...

Türkiye, 2017(Nemrut Dağı): Yaşlı engelli ya da çocuklu insanların dinleneceği tepeye gidene kadar aralarda duraklama yapacakları yer yok.

Türkiye, 2017:... Hem manzara ve doğa oldukça etkileyici. Kartpostalık fotoğraflar çekmek için çok uygun bir nokta.

Ingiltere, 2013 (Nemrut Dağı): Soğuk zirve çok soğuk ve kar var, kalın giyinin başınıza bere elinize eldiven ayağınıza dağlara uygun spor yumuşak tabanlı dişli bir ayakkabı fiziki durumu müsait olmayanlar için çok zor bir yol...

\section{Sonuç ve Tartışma}

Gelişen teknolojiyle sosyal iletişim araçlarının kullanımı artış göstermekte, sosyal medyanın bir bilgi kaynağı olarak kullanımı yaygınlaşmakta, buna bağlı olarak etki alanı genişlemektedir. Bu durum işlevsel açıdan sosyal iletişim ağlarının turistler tarafından bilgi paylaşma ve bilgi edinme amaçı kullanımını arttırmaktadır. Sosyal iletişim ağlarının gelişimiyle birlikte bu ortamlarda yapılan paylaşımlar, turistik bölge yöneticileri ve işletmelerin girişimlerinde, turistik bölgeye yönelik iyileştirme ve geliştirme faaliyetlerinde, potansiyel müşterilerin turistik bölge tercih ve karar süreçlerinde önemli bir işlev görmektedir. Dolaysıyla sosyal iletişim ağlarında paylaşım yapan turistler gerek işletme ve turistik bölge yöneticileri gerekse potansiyel müşteriler için bilgi üretici rol üstlenmektedir. Bu çerçevede hazırlanan araştırmanın amacı, turistlerin sosyal medyada Adıyaman'daki çekiciliklere yönelik yaptığı paylaşımlarla turistik bölge ve işletme yöneticileriyle birlikte, benzer ilgi alanına sahip potansiyel müşteriler için ürettiği bilginin incelenmesidir. Araştırmada, turistlerin bölgedeki çekiciliklerin özelliklerine yönelik 11 farklı kategoride bilgi ürettiği sonucuna ulaşılmıştır. Bu kategoriler; (i) doğal ve turistik kaynaklar, (ii) genel yatırımlar (iii) turistik yatırımlar (iv) turistik eğlence ve aktivite olanakları, (v) turistik eserlerin kültürel, tarihi ve mimari 
değeri (vi) ekonomik ve politik faktörler, (vii) doğal çevre, (viii) sosyal çevre, (ix) turistik bölgenin atmosferi, $(x)$ yetkililer ve çalışanlar ve (xi) önerilerdir.

İlgili alanyazın incelendiğinde, belirlenen kategorilerin alanyazında tespit edilen kategorilerle nispeten benzeştiği görülmektedir. Mevcut çalışmada belirlenen kategoriler Beerli ve Martin'in (2004) ve Dwivedi (2009) turistik bölge imajına yönelik gerçekleştirdikleri araştırmalarda belirlenen kategorilerle örtüşmektedir. Bunun yanı sıra çalışmada belirlenen kategoriler, Sun, Ryan ve Pan (2015) tarafından gerçekleştirilen araştırmada belirlenen turistik bölge imajına ilişkin kentsel ve kırsal kaynaklar, doğal kaynaklar, turistik ve genel yatırımlar, kültür, aktiviteler, politika ve ekonomi kategorileri tespitleriyle örtüşürken, Hao, Xu ve Zhang (2019) tarafından gerçekleştirilen çalışmada belirlenen doğal çevre, kültür, konaklama, iklim, trafik yoğunluğu, aktivite ve rekreasyon olanakları kategorileriyle nispeten benzeşmektedir. Buna karşın, mevcut araştırmada belirlenen bölgedeki eserlerin mimari değeri, sosyal çevre, turistik bölgenin atmosferi, öneriler, yetkililer ve çalışanlar kategorileri alanyazındaki tespitlerden farklılaşmaktadır. Alanyazında turistik bölgelere yönelik sosyal iletişim ağlarında yapılan paylaşımların turistik bölgenin gelişmişlik düzeyi, turistik bölgedeki çekiciliklerin çeşitliliği, bölgeyi ziyaret eden turistlerin demografik özellikleri, seyahat amaçları, intiyaç ve beklentilerine bağlı olarak değişim gösterebileceği yönünde tespitler bulunmaktadır (Yo ve Gretzel, 2011; Wang, 2011; Banyai ve Glover, 2012; Sun ve diğ. 2015; Kim ve Fesenmaier, 2017). Mevcut araştırma ve alanyazındaki sonuçların farklılaşan yönleri söz konusu değişkenlerin etkisiyle açıklanabilir. Bu bağlamda Adıyaman'ın turistik gelişmişlik yönünden, alanyazında değerlendirilen Avrupa ve Asya'daki turistik bölgelerden niceliksel olarak geri kalmışlığı ve bölgeye seyahat eden turist profilinin diğer bölgelerdeki profillerden farklılaşması, turistlerin seyahat esnasındaki algılarını ve tespitlerini etkilemekte, paylaşımların içeriklerinin farklılaşmasına yol açmaktadır.

Araştırma sonuçlarına göre Adıyaman, turistik çekicilikler, çekiciliklerin tarihsel ve mimari özellikleri ve doğal çevresi bakımından güçlü ve gelişim potansiyeline sahip bir turizm bölgesidir. Bölgeyi seyahat eden turistlerin bölge atmosferine ilişkin paylaşımları, turistik çekiciliklere ilişkin puanlamaları, deneyimden tatmin olma durumları ve bölgeyi tavsiye etme niyetlerinin olumlu olması araştırma sonuçlarının birbiriyle örtüştüğünü gösterirken, söz konusu gelişim fırsatının varlığını kanıtlar niteliktedir. Buna karşın araştırma sonuçları bölgede turistik gelişim açısından üst ve altyapı yatırımları, turistik çekiciliklere ulaşım, turistik eserlerin bulunduğu alanlardaki tesisleşme ve çevre düzenlemesi, eğlence ve aktivite olanakları, çalışanların profesyonelleşmesi, halkın turizme katılımı ve bölgenin seyahat acentaları tarafından geçiş noktası olarak konumlandırılması sorunlarının olduğunu göstermektedir. Turistik bölgenin gelişimi, bölgedeki benzersiz çekiciliklerin farkında olma ve değerini bilmekle beraber, sorunları göz ardı etmeksizin mümkün olacaktır (Özdemir, 2008). Sorunların çözümü ve gelişim için turizm sektöründeki her paydaşın sorumluluklarını yerine getirmesi ve paydaşların işbirliği içerisinde hareket etmeleri gereklidir.

Araştırmada Adıyaman'daki turistik gelişim sorunlarının ulusal ve yerel yönetimler, turistik işletmeler ve yerel halk kaynaklı olduğu belirlenmiştir. Bu nedenle turizm faaliyetlerinin geliştirilmesi noktasında söz konusu paydaşlara önemli vazifeler düşmektedir. Ulusal ve yerel yönetimlerin turizmin olmazsa olmazları olarak ifade edilen alt ve üstyapı hizmetlerini iyileştirmesi öncelikli gereksinimdir. Bu bağlamda turistlerin başlıca sorun olarak belirttiği ulaşım altyapısının iyileştirilmesi, tesisleşme ve çevre düzenlemesi faaliyetlerinin turistik eserlerin dokusu ve doğasına zarar vermeyecek biçimde yeniden yapılandırılmasıyla bölgenin turizm pazarından aldığı payın artacağı aşikârdır. Bununla birlikte araştırmada bölgedeki turistik faaliyetlerin 
kültür turizmi ekseninde gerçekleştiği sonucuna ulaşılmıştır. Bölgedeki turistik faaliyetler kültür odaklı faaliyetlere sıkışmasına karşın, bölgede başta doğa, inanç ve spor turizmi olmak üzere turizm aktivitelerinin çeşitlendirilmesine hizmet sunabilecek çekicilikler mevcuttur. Turistik bölgedeki çekiciliklerin her biri kendine özgü özellik ve eşsiz yapıya sahip olduğu göz önüne alındığında kültür öğeleriyle birlikte, alternatif turizm öğelerinde de turizme kazandırılmasının bölgenin rekabet gücünün geliştirilmesine katkı sağlayacaktır. Bu noktada başarı için ulusal ve yerel yönetimlerle bölgedeki işletmelerin işbirliği ve koordinasyon içerisinde olması elzemdir. Nitekim araştırmada bölgenin ve bölgedeki çekiciliklerin tanıtımı noktasında sorunlar olduğu tespit edilmiştir. Dolaysıyla bölgenin tanıtım ve satışında önemli rol üstlenen seyahat acentalarının bölgede turistik öğelerin tanıtım ve farklılaştırmasına yönelik faaliyetlere desteği önemlidir. Adıyaman genel itibariyle acentaların tur güzergâhlarında geçiş noktası olarak konumlandırılmaktadır. Acentalar, turistleri Güneydoğu Anadolu Bölgesine düzenlenen kültür turları kapsamında, Nemrut Dağı'nı ziyaret etmek amacıyla bölgeye getirmekte, bu nedenle bölgedeki turistik çekiciliklerin turistler tarafından bilinirliği sınırlı kalmaktadır. Bu noktada Adıyaman'ın geçiş noktası olarak konumlandığı tur programları yerine bölgenin varış noktası olarak yer aldığı programların düzenlenmesi gelişim açısından elzemdir.

Araştırmada elde edilen bir diğer sonuç, bölgedeki eğlence ve aktivite alanlarının yetersiz olduğunu göstermektedir. Bölgenin turistik varış noktası olarak pazarlanması için turistlerin deneyimlerini farklı kılacak eğlence ve aktivite alanlarının varlığı önemlidir. Bu nedenle yerel yönetim ve işletmelerin aktivite ve eğlence olanaklarını destekleyen yatırımlarının arttırılması bölgede turizm faaliyetlerinin geliştirilmesine katkı sunacaktır. Ayrıca araştırmada işletme personellerinin yetenek ve yeterlilikleri noktasında sorunlar olduğu belirlenmiştir. İşletmelerin personel seçim sürecinde ücret eksenli seçimden ziyade yetenekli personel seçimine odaklanması, iletişim yetenekleri ve yetkinliklerinin geliştirilmesi adına personellerine eğitim vermesi bölgede sunulan turistik deneyim kalitesinin geliştirilmesine yardımcı olacaktır. Tüm bunlarla birlikte araştırmada yerel halkın turizme katılımının ve turistlerin yerel halkla etkileşim düzeyinin düşük olduğu sonucuna varılmıştır. $\mathrm{Bu}$ durum bölgedeki aktivite olanaklarının yetersizliği ve bölgenin geçiş noktası olması sebebiyle turistler ve yerel halk arasındaki sosyal etkileşimi sağlayacak ortamın oluşmamasıyla yakından ilişkilidir. Yerel halk ve turistler arasındaki etkileşimin düşük olması, halkın turizmin faydalarına yönelik farkındalıklarını sınırlarken, turizme yaklaşımını ve duyarlıı̆ını kısıtı kılmaktadır. Bu nedenle bölgedeki turizmin gelişim dinamiklerinin harekete geçirilmesi yoluyla altyapı ve üstyapı yatırımlarının arttırılması, kültür öğelerine sıkışan turistik faaliyetlerinin çeşitlendirilmesi, bölgenin tanıtım faaliyetlerinin arttırıması, turizm için gerekli sosyal ortamın inşası yoluyla turistik çekicilik yönünden zengin Adıyaman'ın turistik durak noktası olması adına önemli işlev görecek ve halkın turizmin ekonomik faydalarından istifade etme düzeyini ve dolaysıyla desteğini arttıracaktır.

Tüm bunlarla birlikte, günümüzün önemli iletişim ve pazarlama alanlarından biri olarak kabul gören sosyal iletişim ağlarının hızlı gelişimi, buna bağlı olarak artan kullanımı bu ağların turizm sektöründeki etki alanını da genişletmektedir. Bu durum sosyal iletişim ağlarında yapılan paylaşımları sektörel ölçekte önemli kılarken, turistik tercih ve girişimlerin bu ağlarda yapılan paylaşımlardan doğrudan etkilenmesine yol açmaktadır. Bilhassa turizm sektörünün talep öğesi olan turistler tarafından yapılan paylaşımların, bir yandan işletmeler öte yandan potansiyel turistler için önemli bir bilgi kaynağı işlevi görmesi sosyal iletişim ağlarında yapılan paylaşımları önemli kılmaktadır. Dolayısıyla Adıyaman'da faaliyet gösteren işletmelerin teknolojik uygulamalara ve sosyal iletişim ağlarına yönelik yatırımlarıyla birlikte, hizmet geliştirme ve iyileştirme girişimlerine bu ağlarda yapılan paylaşımlar ve değerlendirmeleri analiz 
ederek yön vermesinin bölgede turizmin gelişimine katkı sunacağı aşikârdır. Buna karşın teknolojiyle entegre uygulamaların yüksek maliyetler gerektirmesi işletmelerin sosyal iletişim ağlarından etkin ve verimli yararlanmasını kısıtlamaktadır. Bu bağlamda bölgede turizminin uzun vadeli gelişimini destekleyecek teknolojik yatırımların yapılması adına çalışmaların yapılması elzemdir. Teknolojik yatırımları ve sosyal iletişim ağları üzerinde kontrolü artan paydaşların turistleri kontrolü kolaylaşacak, turistleri anlama kabiliyetleri artacak ve sektörel ölçekte gözlemlenen sorunları tespit etme ve sorunlara müdahale gücü gelişecektir. Aynı zamanda sektörel ölçekte gözlemlenen sorun ve hataların azaltılması olanaklı hale gelerek, bölgenin rekabet gücünün geliştirilmesi noktasında önemli fırsatlar elde edilecektir.

Araştırmada Adıyaman'daki turistik çekicilikler üzerine TripAdvisor sitesinde yapılan yorumlar incelenmiştir. İlerleyen araştırmalarda Facebook, Instagram ve Twitter gibi sanal toplulukların bir araya geldiği ortamlarda yapılan paylaşımların incelenmesi daha geniş bir çerçeveden bölgenin değerlendirilmesini sağlayabilecektir. Bununla birlikte araştırmada turistik bölgedeki çekiciliklere dair paylaşımlar incelenmiştir. Bu çerçeve gelecekte hazırlanacak araştırmalarda konaklama, yiyecek ve içecek gibi turistik işletmelere yönelik sosyal iletişim ağlarında yapılan paylaşımların incelenmesi bölge turizminin bütüncül bakış açısıyla değerlendirmesine katkı sağlayacağı aşikârdır.

\section{Kaynakça}

Akyurt, H. ve Atay, L. (2009). Destinasyonda imaj oluşturma süreci. Aksaray Üniversitesi IiBF Dergisi. 1 (1): 1-14.

Arıca, R. (2019). Seyahat acentalarında turistik ürünlerin kişiselleştirilmesinin bir yolu olarak müşterilerle üretim. Türk Turizm Araştırmaları Dergisi. 3 (3): 499-516.

Arıca, R. ve Çorbacı, A. (2019). Müşterilerin ortak üreticilik rolünü konu edinen araştırmaların incelenmesi: Scopus veri tabanında taranan turizm ve otelcilik dergilerinin bibliyometrik açıdan değerlendirilmesi. Turizm Akademik Dergisi. 5 (1): 263-276.

Arıca, R. ve Kozak, R. (2018). Seyahat acentalarında müşterilerin üretime katılım davranışının algılanan hizmet çıktılarına etkisi. Seyahat ve Otel İşletmeciliği Dergisi. 15 (3): 684-702.

Avcıkurt, C. (2010). Turizmde Tanıtma ve Satış Geliştirme. (3. Baskı). İstanbul: Değişim Yayınları.

Baloglu, Ş. ve McCleary, K.W. (2009). A model of destination image formation. Annals of Tourism Research. 26 (4): 868-897.

Banyai, M. ve Glover. T.D. (2012). Evaluating research methods on travel blogs. Journal of Travel Research. 51 (3): 267-277.

Beerli, A. ve Martin. J.D. (2004). Factors influencing destination image. Annals of Tourism Research. 31 (3): 657-681.

Berezina, K.; Bilgihan, A.; Çobanoğlu, C. ve Okumus, F. (2016). Understanding satisfied and dissatisfied hotel customers: Text mining of online hotel reviews. Journal of Hospitality Marketing and Management. 25 (1): 1-24.

Brandsen, T ve Pestoff, V. (2006). Co-production, the third sector and the delivery of public services. An introduction. Public Management Review. 8 (4): 493-501.

Brochado, A.; Rita, P.; Oliveira, C. ve Oliveira, F. (2019). Airline passengers' perceptions of service quality: themes in online reviews. International Journal of Contemporary Hospitality Management. 31 (2): 855-873.

Buhalis, D. ve Foerste, M. (2015). SoCoMo marketing for travel and tourism: Empowering co-creation of value. Journal of Destination Marketing and Management. 4: 151-161. 
Bulut, Z.A. ve Karabulut, A.N. (2018). Examining the role of two aspects of eWOM in online repurchase intentions: An integrated trust-loyalty perspective. Journal of Consumer Behaviour. 17 (4): 407-417.

Chen, C.F. ve Tsai, D. (2007). How destination image and evaluative factors affect behavioral intentions?. Tourism Management. 28 (4):1115-1122.

Crompton, J.L. (1979) An assessment of the image of Mexico as a vacation destination and the influence of geographical location upon the image. Journal of Travel Research. 18: 18-23.

Dwivedi, M. (2009). Online destination image of India: A consumer based perspective. International Journal of Contemporary Hospitality Management. 21 (2): 226-232.

Gao, S.; Tang, O.; Wang, H. ve Yin, P. (2018). Identifying competitors through comparative relation mining of online reviews in the restaurant industry. International Journal of Hospitality Management. 71: 19-32.

Hao, X.; Xu, S. ve Zhang, X. (2019). Barrage participation and feedback in travel reality shows: The effects of media on destination image among generation Y. Journal of Destination Marketing and Management. 12: 27-36.

Jacobsen, J. K. S. ve Munar, A. M. (2012). Tourist information search and destination choice in a digital age. Tourism Management Perspectives. 1: 39-47.

Kim, J. ve Fesenmaier, D.R. (2017). Sharing tourism experiences: The posttrip experience. Journal of Travel Research. 56 (1): 28-40.

Kim, B.; Kim, S. ve Heo, C.Y. (2015). Analysis of satisfiers and dissatisfiers in online hotel reviews on social media. International Journal of Contemporary Hospitality Management. 28 (9): 1915-1936.

$\mathrm{Li}, \mathrm{X}$. ve Petrick, J.F. (2008). Tourism marketing in an era of paradigm shift. Journal of Travel Research. 46 (3): 235-244.

Mahtis, E.F.; Kim, H.; Uysal, M.; Sirgy, J.M. ve Prebensen, N.K. (2016). The effect of co-creation experience on outcome variable. Annals of Tourism Research. 57: 62- 75.

Messner, W. (2017). Does value for money create advocates? A study in the international airline services industry. Journal of Global Marketing. 30 (5): 309321.

Molinillo, S.; Liebana-Cabanillas, F.; Anaya-Sanchez, R. ve Buhalis, D. (2018). DMO online platforms: Image and intention to visit. Tourism Management. 65: 116130.

Munar, A. M. ve Jacobsen, J.KS. (2014). Motivations for sharing tourism experiences through social media. Tourism Management 43:46-54.

Narangajavana, Y.; Fiol, L.J.C.; Tena, M.A.M.; Artola, R.M.R. ve Garcia, J.S. (2017). The influence of social media in creating expectations. An empirical study for a tourist destination. Annals of Tourism Research. 65: 60-70.

Qualman, E. (2012). Socialnomics: How Social Media Transforms the Way We Live and Do Business. (Second Edition). New Jersey: John Willey ve Sons.

O'Connor, P. (2008). User-generated content and travel: a case study on Tripadvisor.com. Information and Communication Technologies in Tourism. Wien, Springer, pp: 47-58.

O'Connor, P. (2010). Managing a hotel's image on tripadvisor. Journal of Hospitality Marketing ve Management. 19: 754-772.

Özdemir, G. (2008). Destinasyon Pazarlaması. Ankara: Detay Yayıncılık.

Parks, R.B.; Baker, P.C.; Kiser, L.; Oakerson, R.; Ostrom, E.; Ostrom, V.; Percy, S.L.; Vandivort, M.B.; Whitaker, G.P. ve Wilson, R. (1981). Consumers as coproducers of public services: some economic and institutional considerations. Policy Studies Journal. 9 (7): 1001-1011.

Payne, A.F.; Storbacka, K. ve Frow, P. (2008). Managing the co-creation value. Journal of the Academy of Marketing Science. 36 (1): 83-96. 
Pearce, P. L. (2012). Tourists written reactions to poverty in Southern Africa. Journal of Travel Research. 51 (2): 154-165.

Rihova, I.; Buhalis, D.; Moital, M. ve Gouthro, M.B. (2015). Conceptualising customerto-customer value co-creation in tourism. International Journal of Tourism Research. 17: 356-363.

Rihova, I.; Buhalis D.; Gouthro, M.B. ve Moital, M. (2018). Customer-to-customer cocreation practices in tourism: Lessons from customer-dominant logic. Tourism Management. 67: 362-375.

Sharda, N. ve Ponnada. M. (2008). Tourism blog visualizer for better tour planning. Journal of Vacation Marketing. 14 (2): 157-167.

Sun, M.; Ryan, C. ve Pan, S. (2015). Using Chinese travel blogs to examine perceived destination image: The case of New Zealand. Journal of Travel Research. 54 (4) $543-555$.

Tussyadiah, L. P. ve Fesenmaier. D.R. (2008). Marketing places through first-person stories. An analysis of Pennsylvania roadtripper blog. Journal of Travel and Tourism Marketing. 25 (3): 299-311.

Volo, S. (2010). Bloggers reported tourist experiences: Their utility as a tourism data source and their effect on prospective tourists. Journal of Vacation Marketing. 16 (4): 297-311.

Wang, H.Y. (2011). Exploring the factors of gastronomy blogs influencing readers' intention to taste. International Journal of Hospitality Management. 30: 503-514.

Wang, Y. ve Fesenmaier, D.R. (2004). Towards understanding members' general participation in and active contribution to an online travel community. Tourism Management. 25: 709-722.

Yeşilyurt, H. ve Arıca, R. (2018). Mutfak müzesi ziyaretçilerinin deneyimlerinin incelenmesi: Emine Göğüş Mutfak Müzesi örneği. Türk Turizm Araştırmaları Dergisi. 2 (1): 60-70.

Yoo, K. H. ve Gretzel, U. (2009). Comparison of deceptive and truthful travel reviews. Information and Communication Technologies in Tourism. ENTER 2009, Proceedings of the International Conference in Amsterdam. Netherlands. 37-47.

Yoo, K. H. ve Gretzel, U. (2011). Influence of personality on travel-related consumergenerated media creation. Computers in Human Behavior. 27 (2): 609-621.

Zeng, B. ve Gerritsen, R. (2014). What do we know about social media in tourism? A review. Tourism Management Perspectives. 10. 27-36.

Zhao, Y.; Xu, X. ve Wang, M. (2019). Predicting overall customer satisfaction: Big data evidence from hotel online textual reviews. International Journal of Hospitality Management. 76: 111-121.

Zhang, Y. ve Cole, S.T. (2016). Dimensions of lodging guest satisfaction among guests with mobility challenges: A mixed-method analysis of web-based texts. Tourism Management. (53):13-27.

Zhang, Z.; Ye, Q.; Law, R. ve Li, Y. (2010). The impact of e-word-of-mouth on the online popularity of restaurants: A comparison of consumer reviews and editor reviews. International Journal of Hospitality Management. 29 (4): 694-700.

https://www.tripadvisor.com.tr/ (Erişim Tarihi: 08.06.2019)

https://www.tripadvisor.com.tr/Attractions-g297957-Activities-Adiyaman.html (Erişim Tarihi: 15.06.2019) 